\title{
Developing Birth Preparedness and Complication Readiness (BPCR) Screening Based on Android Applications
}

\author{
Desi Sarli ${ }^{\mathrm{a},}$, Faridah Mohd Said ${ }^{\mathrm{b}}$, Ali Ameen ${ }^{\mathrm{c}}$, Imam Gunawan ${ }^{\mathrm{c}}$ \\ ${ }^{a}$ Health Science, Lincoln University College, Wisma Lincoln No 12-18, SS 6/12 street, Petaling Jaya, 47301, Malaysia \\ ${ }^{b}$ Nursing, Lincoln University College, Wisma Lincoln No 12-18, SS 6/12 street, Petaling Jaya, 47301, Malaysia \\ ${ }^{c}$ Information Technology, Lincoln University College, Wisma Lincoln No 12-18, SS 6/12 street, Petaling Jaya,47301, Malaysia \\ Corresponding author: *desi_sarli@yahoo.com
}

\begin{abstract}
Maternal Mortality Rates (MMR) in Indonesia are still relatively high and not yet to reach the Sustainable Development Goals (SDGs) target of MMR in 2014 of 133/100,000 live births. One of MMR's causes is due to 3 delays, namely the delay in the introduction of danger signs and decisions, new arrivals at health facilities, and delays in service at health facilities. For prevention purpose, a Birth Preparedness and Complication Readiness (BPCR) screening application are needed. This application aims to do labor planning and determine the risk of pregnancy so that the mother is ready to face the risk of complications at delivery. This research method uses a prototype method of designing and building applications. For testing this application, researchers conducted a BPCR screening test on 30 pregnant women. Then the data is tested for validity and reliability using sensitivity and specificity tests. This study's results can display the main page application, Birth Preparedness of the Application, Complication Readiness of the Application. The Result of BPCR of the Application. This application has been tested for validity and reliability by using a sensitivity test of $83 \%$ to determine the high/moderate risk of pregnancy that experiences complications during labor. At the same time, the specificity test was $\mathbf{7 7 . 7 8 \%}$ to determine the low risk of pregnancy that did not experience difficulties during labor.
\end{abstract}

Keywords - Birth preparedness and complication readiness; BPCR; screening; android application.

\section{INTRODUCTION}

Maternal mortality rates (MMR) since 2010, 2012 and 2014, Indonesia has the highest MMR of the five countries in Southeast Asia (Indonesia, Malaysia, Brunei, Thailand, Singapore). Where the MMR of Indonesia since 2014 was 133 / 100,000, in 2012, $148 / 100,000$, and in 2010 it was 165 / 100,000. Although MMR has declined since 2010, MMR is still far from the target sustainable Development Goals (SDGs), namely the number of MMR of $70 / 100,000$ live births [1].

Based on the 2012 Indonesian Demographic and Health Survey, MMR (related to pregnancy, childbirth, and postpartum) was 359 per 100,000 live births, while neonatal deaths were $32 / 1000$ live births. The average mortality rate is much higher than the Indonesian Demographic and Health Survey results in 2007, which reached a Maternal Mortality Rate of 228/100,000 live births and a neonatal mortality rate of 19/1000 live births [2].
Three delays cause high maternal and newborn mortality rates: delays in introducing warning signs and decisions, new arrivals at health facilities, and delays in service at health facilities [3]. To prevent maternal and newborn deaths, it is necessary to make a model of delivery planning and prevention of complications [4].

This model is based on the assumption that knowledge of danger signs and readiness to handle obstetric complications ensures that predictable elements of three delays can be anticipated, identified in time, and handled immediately during delivery planning [5]. Delays in seeking care are caused by failure to recognize signs of complications or perception of disease severity, consideration of prior costs, and previous negative experiences with the health care system [6]. Delays in achieving care may be due to the distance from a woman's home to a health facility, poor road conditions, and the absence or irregularity of emergency transportation [7]. Delays in receiving care may be due to health workers' negative attitudes, lack of essential supplies and equipment, 
lack of health workers, and poor health service provider skills [8].

Therefore it is necessary to develop an application to overcome maternity delays by developing the BPCR application [9]. Current technological advances allow one to be able to maximize smartphone functions with applications that can make it easier to provide information to users [10]. The BPCR application will be made in the android digital system, where the BPCR application functions to filter the results of pregnancy examinations and preparation for delivery and preparedness for complications [11]. With Android-based BPCR, Screening is expected to help reduce MMR and NMR.

The growth of the digital society in Indonesia also shows very rapid growth [12]. The number of active internet users reached 88.1 million from 252.4 million Indonesians in 2014, with penetration reaching $34.9 \%$. Internet users in all provinces in Indonesia most often access the internet using a smartphone [13]. Based on the background, researchers are interested in researching to develop Readiness and Complications Readiness (BPCR) Based on Android Applications.

\section{MATERIALS AND METHOD}

This research uses a prototype method of designing and building applications. The prototyping methodology is defined as a Software Development model in which a prototype is built, tested, and then reworked as needed until an acceptable prototype is reached. This also creates the basis for producing the final system. The prototyping software model works best in scenarios where project requirements are unknown. This is a repeated method, trial, and error that occurs between the developer and the client [14].

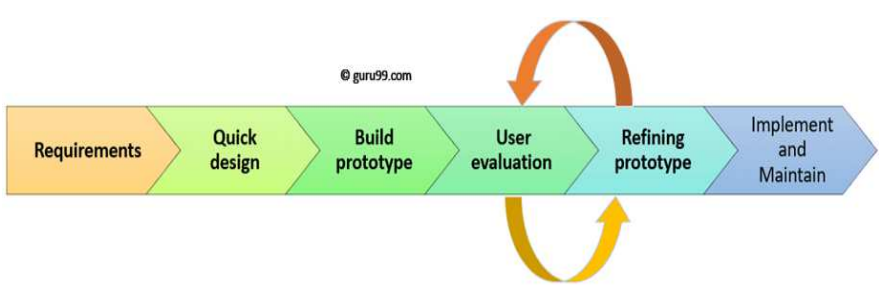

Fig.1 Model Prototyping Phase [14]

The Prototyping Model has followed the six phases of SDLC as follows [14]:

1) Step 1: Requirement collection and analysis: The prototype model starts with a need's analysis. In this phase, system requirements are defined in detail. During the process, system users are interviewed to find out what they expect from the system.

2) Step 2: Quick design: The second phase is the initial design or fast design. At this stage, a simple system design is created. However, it is not a complete design. This gives users a quick overview of the system. Rapid design helps in developing prototypes.

3) Step 3: Build Prototypes: In this phase, the prototype is designed based on the fast design information. This is a small working model of the system that is needed. To test this application, the researchers conducted a BPCR screening test on 30 pregnant women, whose data was then tested for validity and reliability using sensitivity and specificity tests. This method is in the form of a diagnostic confirmation tool in the form of a $2 \times 2$ tabulation that results in sensitivity, specificity, predictive value, and prevalence. Sensitivity is the possibility of a case being diagnosed correctly or the probability of each case being identified by a screening test. Sensitivity is described as the percentage of people with the disease who test positive [15].

The formula of Sensitivity we can see equation 1 :

$$
\text { sensitivity }=\frac{\text { true positive }}{\text { True Positive }+ \text { False Negative }} X 100
$$

White specificity is based on the Epidemiology Dictionary is the proportion of people who are not sick and not sick anyway when identified by screening tests. This is a measure of the likelihood of correctly identifying a person who is not sick with a screening test. Specificity is a measure that measures how well a screening test classifies people who are not sick as true people who do not have the disease in reality [16].

The formula of specificity we can see in equation 2 :

$$
\text { specificity }=\frac{\text { true negative }}{\text { False Positive }+ \text { True Negative }} X 100
$$

Positive Predictive Value (PPV) is the proportion of positive patients (true positive) among all patients who show positive confirmation test results. This value explains how likely it is that positive test results indicate disease. The formula of PPV we can see equation 3:

$$
P P V=\frac{\text { true positive }}{\text { True Positive }+ \text { False Positive }} X 100
$$

Negative Predictive Value is the percentage of all truly negative (healthy/true negative) patients among all patients who show negative test results. The formula of PPV we can see equation 4:

$$
N P V=\frac{\text { true negative }}{\text { True Negative }+ \text { False Negative }} X 100
$$

When compared with the gold standard examination, a positive predictive value is a probability that a subject identified positively by the measuring instrument will be positive according to the gold standard later. Whereas, the negative predictive value is the probability that a subject identified negatively by the measuring instrument will be truly negative according to the gold standard later.

\section{RESULT AND DISCUSSION}

\section{A. BPCR Development based on Android Application}

The BPCR model is an application built on Android OS. The application offers several services that are provided by the BPCR's main website and makes them available to users on a mobile platform. These services or features include detailed biodata such as Name, Address, Education, Occupation, and filler date. This chapter covers all the features of the application. The main page of the application is shown in Figure 2. 


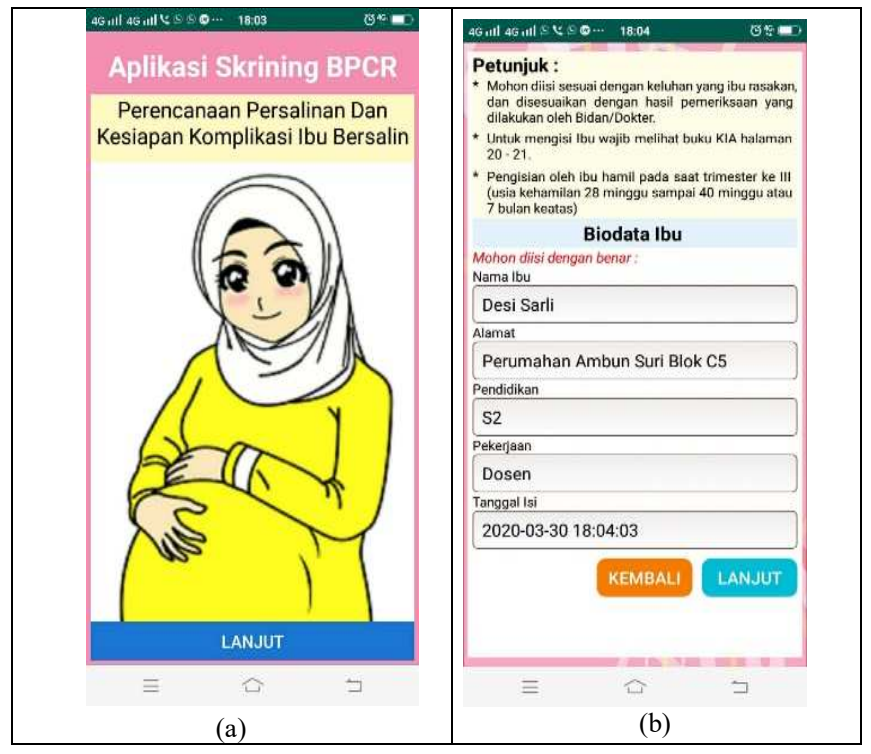

Fig. 2 Screenshot of The Main Page of The Application

The next page is in the form of questions about Birth Preparedness such as transportation, Labor Companion, decision-maker, blood donor. Before proceeding to the next page, mothers must fill in questions on number 5 that ask whether the mother routinely checks the pregnancy to the health worker; if the mother answers "no," then the mother cannot proceed to the next page. The question about birth preparedness is shown in figure 3 .

BPCR is a strategy that helps women to consider all maternal health care services available during pregnancy and prepare for possible complications. As many as $48.5 \%$ of women prepare for their baby's birth and are ready for its complications. women advise to prepare potential blood donors $(\mathrm{AOR}=1.90,95 \% \mathrm{C} . \mathrm{I}=1.15,3.12)$ and women whose partners and / or families are counseled $(\mathrm{AOR}=2.16$, $95 \% \mathrm{CI}=1,25,3,74)$ are positive factors associated with birth readiness and the practice of readiness for complications [17].

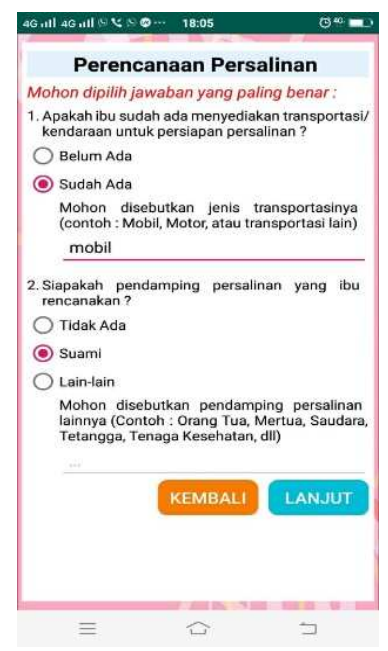

(a)

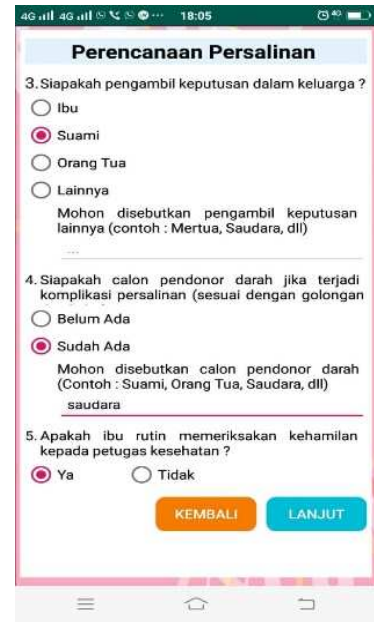

(b)
Fig. 3 Screenshot of Birth Preparedness of the Application

The next page is the question of Complication Readiness, which can be seen in Figure 4. Screening Complication Readiness, among others: Age, Age of Pregnancy, Arm Circumference, Parity, Mode of last delivery, Blood Pressure, signs of anemia, the amusement of pregnancy, Odema in pregnancy, antepartum hemorrhage, fetal location, fetal heart rate, laboratory tests including hemoglobin, urine protein, glucose, hepatitis, and HIV.

The age in the application "If the mother's age is between 17 to 34 years, then the score $=0$ If the mother's age $<17$ or $>$ 34 years, then the score $=4 "$. This is supported by the results of research stating that maternal who is less than 20 years old or more than 35 years old are at risk of experiencing childbirth complications by 1.3 times compared to mothers aged 21-34 years. Pregnant women under the age of 20 years are more at risk of abortion, anemia, malnutrition, hypertension, preeclampsia, and eclampsia [18].

The application can determine of First Day of Last Menstruation to find out the Maternal Pregnancy Age and Estimated delivery with the formula "Pregnancy Age = Date of contents - date of First Day of Last Menstruation (in weeks)". If the gestational age is 42 weeks, then a score of 4 will appear advice should the mother end the pregnancy for avoiding complications for the fetus and mother, if gestational age $<42$ weeks, then a score of 0 . Date of Interpretation of Childbirth $=$ Date of First Day of Last Menstruation +40 Weeks or 280 days. The age of serotinus pregnancy in the application will be given a high-risk score, where there is a relationship between serotine pregnancy and asphyxia in newborns ( $p$-value $<0.05$ ). Serotinus pregnancy is a risky pregnancy. Serotinus pregnancies are more likely to have labor complications with oligohydramnios, macrosomia, amniotic fluid mixed with meconium, shoulder dystocia, asphyxia, and hysterectomy ( $\mathrm{p}<0.05$ in all). Perinatal mortality rates were significantly higher at post term as well [19]. Determining the gestational age is also more effective if using ultrasound to prevent errors in determining the gestational age [20].

The application can determine about Upper arm circumference in $\mathrm{cm}$, if the circumference of the upper arm $\geq$ $23 \mathrm{~cm}$, then a score of 0 if the upper arm circumference is $<$ $23 \mathrm{~cm}$, a score of 4 and application will give suggestion Mothers should routinely examine pregnancy to health workers, and eat nutritious foods so that nutritional needs for both mother and fetus can be met. Arm circumference less than $23.5 \mathrm{~cm}$ is stated that pregnant women experience Chronic Energy Deficiency and experience 7 times more risk of giving birth Low Birth Weight [21]. Chronic Energy Deficiency (CED) also has the potential to experience asphyxia in newborns [22], CED also caused an increased incidence of Stunting [23] then the application will be given a high-risk score.

In the Application, if parity to $\leq 4$, then a score of 0 , and if pregnant $>4$ then a score of 4 , the application will give suggestions maternal routinely carry out pregnancy checks at least once a month to the health worker. Maternal with high parity will have a greater risk of the incidence of labor complications, especially postpartum hemorrhage [18]. In mothers who frequently give birth, the uterine muscles are often stretched, resulting in thinning of the uterine wall, which eventually causes the uterus' contraction to become weak. Uterine rupture is a complication of labor that often occurs in mothers who have previously given birth to several children [2]. 
The final mode of delivery also determines maternal delivery in the application, if the delivery is normal score $=0$, if the answer is Vacuum, Score $=4$ and Cesarean section, Score $=8$ it would be advisable for the next delivery of the mother to give birth with a health worker. The study results stated that there is a significant relationship between the history of childbirth with the incidence of cesarean section. The analysis results obtained OR value $=5.716$ means that the group of women who have a history of childbirth with an action or sectio Caesarea has a chance of giving birth 6 times with sectio Caesarea compared to women with a history of spontaneous labor [24]. The history of labor has a major influence on the incidence of Sectio Caesarea, this is because the mother with a history of Sectio Caesarea has a scar on the uterus so that if spontaneous labor is performed there is a risk of uterine rupture [2].

The application will give a score 0 if the maternal answer "No" for blood pressure $<140 \mathrm{mmHg}$, and the score 4 if blood pressure $\geq 140 \mathrm{mmHg}$ then the application will give suggestions mothers should routinely conduct pregnancy checks at the health center/hospital at least once a week. Mothers are succumbed to do a laboratory examination if the results of urine protein $(+)$ then the mother is diagnosed with pre-eclampsia, if negative then the mother is diagnosed with hypertension in pregnancy. This is supported by the results of the study stating that there is a relationship of hypertension history with the incidence of pre-eclampsia $(p<0.005)$. Preeclampsia is defined as the onset of hypertension accompanied by proteinuria at gestational age more than 20 weeks or immediately after delivery [25]. Preeclampsia is a multi-system disorder in pregnancy characterized by endothelial dysfunction, increased blood pressure due to vasoconstriction, proteinuria due to glomerular failure, and edema due to increased vascular permeability [26].

On application also assess the signs of anemia, if the mother feels signs of anemia such as feeling tired, tired, frail, weak, it is indicated that the woman has anemia, then the mother will be given a score 4 , if not then a score of 0 is given. An application will advise if the mother feels a sign of anemia such as the mother should go to the health center/hospital for a hemoglobin metabolic examination. If the mother's hemoglobin $<11 \mathrm{gr} \%$, then the mother has anemia. Maternal with anemia can experience postpartum hemorrhage, preterm labor [27], infection, and low birth weight babies [28].

The application assesses the multiple pregnancies is a highrisk pregnancy and gets a score 4, in the application the mother is advised to check her pregnancy at least once a week to monitor fetal well-being. This is supported based on the results of the study of multiple pregnancies at risk of hypertension [29], gestational diabetes mellitus, polyhydramnios, premature rupture of membranes, and abruptio placenta and a lower incidence of severe postpartum hemorrhage [30].

Assessment on the application about antepartum hemorrhage is given 8 scores because antepartum hemorrhage will be difficult for labor, if not then a score 0 . An application will appear advised mothers should check with a doctor for an ultrasound. There are several possible diagnoses, namely placenta previa (placenta that covers the birth canal) or placental solution (placenta that is released in the uterus before the fetus is born, which is usually accompanied by severe pain). Mothers should reduce physical activity and marital relations. The main cause of antepartum bleeding is placenta previa which will cause maternal and neonatal mortality [31].

Assessment on the application about the breach fetal location is a risk of pregnancy and get the score 8 , if not get score 0 . An application will appear suggestion because of the location of the breach fetus or latitude, the mother should check with a doctor for an ultrasound. Mothers are often advised to prostrate to change the location of the fetus into the head (more effectively done before 36 weeks/9 months of gestation). The breach is at risk of giving birth to asphyxia and has complications in labor [32]. Likewise, fetal heart rate> $160 \mathrm{x} / \mathrm{min}$ or $<120 \mathrm{x} / \mathrm{min}$ is a sign of fetal distress that increases birth asphyxia and increases neonatal mortality.

The application assesses the laboratory tests screened for hemoglobin, urine protein, glucose, hepatitis, and HIV. The purpose of laboratory tests in pregnancy is related to a diagnosis of pregnancy that is not good, namely the risk of stillbirth, premature labor, and intrauterine growth retardation [33]. There are three answers for the question of urine protein laboratory results: if the answer has not been checked, score 0 , and will appear suggestions immediately examine the Laboratory. If the answer is positive, a score $=4$ and it is recommended that the mother immediately consult a doctor or midwife so that labor and planning can be done according to the laboratory results. If the answer is negative the score 0 . Positive urine protein, the mother is diagnosed with preeclampsia. It is then necessary to conduct strict supervision by health workers to reduce maternal and neonatal mortality [26].

Glucose testing in pregnancy can determine the mother has diabetes in pregnancy. In Application, if a negative glucose laboratory result is given a score of 0 , if positive get a score of 4 and the application gives the advised to immediately consult a doctor or midwife so that labor can be carried out and planning according to the laboratory results. Based on the research the mother who has gestational diabetes mellitus has the interaction between Gestational Diabetes and Complication of Maternal Labor with OR value in maternal labor complication $=2.904$ [34]. A complication of gestational diabetes mellitus are macrosomia, shoulder dystocia and stillbirth were similar in two groups, while that of preterm labor, preeclampsia, caesarian section, large for gestational age, neonatal ICU admission, and neonatal hypoglycemia were significantly higher in gestational diabetes mellitus $\mathrm{p}<0,05$ [35].

Hepatitis laboratory examination results in the application if the answer has not been checked, then score $=0$ will appear suggestions immediately examine the Laboratory. If the answer is negative with score $=0$. If the answer is positive get a score 8 will appear suggestion to consult a doctor or midwife immediately so that labor and planning can be done according to the laboratory results. Hepatitis $\mathrm{C}$ in pregnancy is on the rise, and antiviral agents that act directly are available to cure this disease. Published recommendations need to be reviewed and evaluated clinically for the care of pregnant women who are at risk or have chronic hepatitis C. Available evidence and some medical and ethical reasons for considering universal screening and antepartum therapy for hepatitis C during pregnancy are presented. Universal screening and proactive 
care during pregnancy are on the horizon, and these steps must be immediately evaluated for safety and implemented if appropriate [36].

Screening HIV on the application needed, results of HIV laboratory testing if the answer has not been checked score 0 will appear suggestions immediately examine the laboratory. If the answer is negative score 0 , if the answer is positive, a score 8 will appear suggestion to consult a doctor or midwife immediately, so that labor and planning can be done by the results of the laboratory. Vertical transmission of HIV

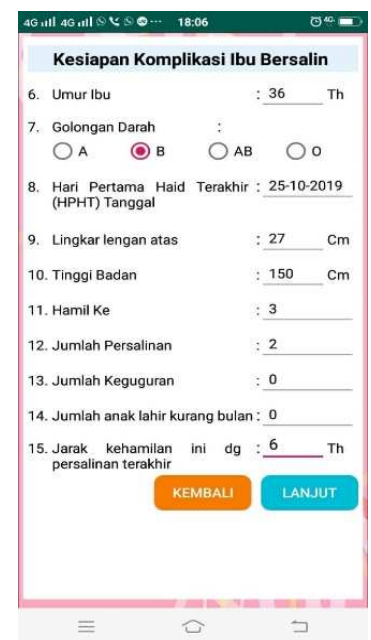

(a)

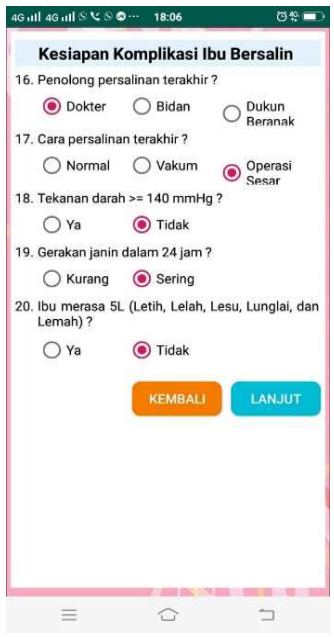

(b) infection from mother to fetus. However, the prevention interventions available are very effective. This review summarizes the evidence regarding screening prevention from mother to fetal transmission to help health workers choose optimal antenatal screening strategies [37]. In Ethiopia, only $35.1 \%$ were tested for HIV and received the test results during pregnancy. About one-third of women who had antenatal care follow-up missed the opportunity to be tested for HIV, so this will increase the risk of HIV transmission from mother to fetus [38].

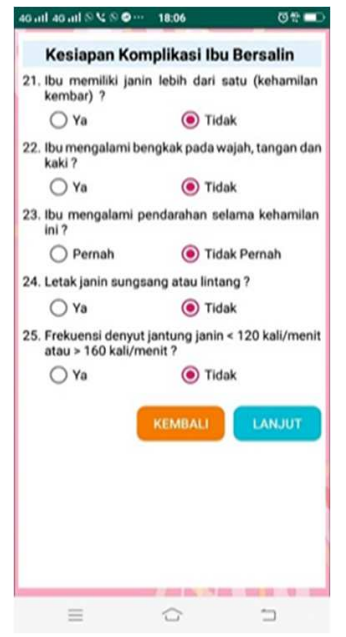

(c)

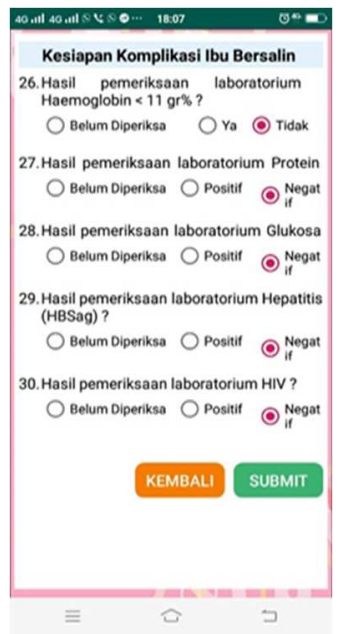

(d)
Fig. 4 Screenshot of Complication Readiness of The Application
The final page will appear as a result of BPCR as shown in Figure 5, this feature will display Estimated delivery and gestational age-adjusted to completed, Pregnancy Risk is divided into three, namely low risk, moderate risk, and high risk, where this feature is based on filling from Complication Readiness. from the risk of pregnancy will determine the helper birth and place of delivery. While childbirth assistance, blood type, blood donor candidates, and transportation based on the filling of Birth Preparedness which is filled by maternal.

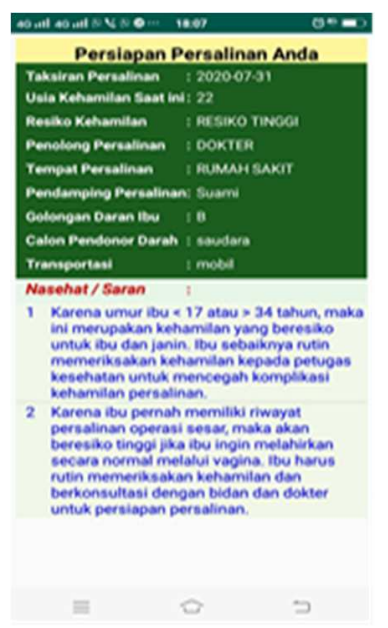

Fig. 5 Screenshot of the Result of BPCR of the Application
BPCR is a strategy that helps women to consider all maternal health care services available during pregnancy and prepare for possible complications. Although the annual number of global maternal deaths decreased to around 303,000 in 2015, avoidable morbidity and mortality remain a formidable challenge in many developing countries which accounted for about $99 \%(302,000)$ of global maternal deaths in 2015 [17].

\section{B. Validity and Reliability}

To test the validity and reliability of the BPCR application, the researchers used the test sensitivity, specificity, predictive value, and prevalence which can be seen in table 1 . It shows the sensitivity value of $83 \%$ and specificity of $77.78 \%$. It can be concluded that the BPCR screening results can determine the risk of high or moderate pregnancy with the incidence of mothers who have complications at delivery around $83 \%$. The BPCR screening results can determine the risk of pregnancy is low with the incidence of mothers who did not experience difficulties during labor can be determined around $77.78 \%$. Whereas the result of positive predictive value (PPV) is lower than the negative predictive value (NPV). These results indicate the results of high/moderate risk screening in pregnancy can predict mothers experiencing the incidence of childbirth complications by $71.4 \%$, while the results of lowrisk screening in pregnancy can predict that mothers do not experience the incidence of childbirth complications by $87.5 \%$. 
TABLE I

VALIDITY AND RELIABILITY SCREENING BPCR BASED ON ANDROID APPLICATION

\begin{tabular}{lcccccc}
\hline \multirow{2}{*}{ BPCR Screening } & \multicolumn{7}{c}{ Complication of Labor } & \multicolumn{3}{c}{ Validity \% } \\
\cline { 2 - 7 } & Yes & No & Sensitivity & Specificity & PPV & NPV \\
\hline High/Moderate Risk & 10 & 4 & 83 & 77.78 & 71.4 & 87.5 \\
Low risk & 2 & 14 & & & & \\
Total & $\mathbf{1 2}$ & $\mathbf{1 8}$ & & & & \\
\hline
\end{tabular}

The most risk factors for pregnancy can be seen from the reproductive status of age, several parties, labor intervals. Mothers aged $<20$ years, physically, psychologically, and socially are not ready to experience pregnancy, childbirth, and childbirth. While women who are pregnant at too old age $(>$ 35 years) face risks when giving birth. Previous studies report that severe preeclampsia in the group of pregnant women aged $20-35$ years $(12.8 \%)$ is more common than the group of women aged 35 years) at greater risk of bleeding before birth. Besides, age is also related to parity, mothers with parity $\geq 4$ times the risk of developing obstetric complications are higher than mothers with low parity ( $<4$ times) [18].

Parity is an important risk factor for obstetric complications, pregnant women with high parity tend to experience placenta previa, resulting in imperfect endometrial growth. The results of this study are also by the theory, that mothers with parity $\geq 4$ times the risk of bleeding and pregnancy poisoning that is greater than parity. Percentage of deliveries at intervals of less than 24 months (too often) Nationally $8.5 \%$ constitute a high-risk group for obstetric complications. Stated birth spacing is a risk factor for pregnancy, which indirectly threatens mothers' lives because it can worsen the state of complications at the time of delivery [39].

\section{CONCLUSION}

The BPCR Screening Application can determine Delivery Planning and Readiness Complications with estimated delivery results, gestational age, pregnancy risk, delivery assistance, place of delivery, delivery attendant, Blood Type, blood donor candidates, and Transportation. This application has been tested for validity and reliability by using a sensitivity test of $83 \%$ to determine the high/moderate risk of pregnancy that experiences complications during labor. Whereas the specificity test was $77.78 \%$ to determine the low risk of pregnancy that did not experience complications during labor. The result of a positive predictive value (PPV) is lower than a negative predictive value (NPV).

\section{ACKNOWLEDGMENT}

I would like to thank STIKes Alifah Padang for providing its support in the form of a scholarship to carry out a Ph.D. education at Lincoln University College. Thank you to the supervisor, who has provided many directions in conducting this research.

\section{REFERENCES}

[1] World Development Indicators, "Global Data Maternal Mortality," 2019.

[2] World Health Organization, Managing Complications in Pregnancy and Childbirth: 2019.

[3] D. B. Endeshaw, L. D. Gezie, and H. Y. Yeshita, "Birth preparedness and complication readiness among pregnant women in Tehulederie district, Northeast Ethiopia: a community-based cross-sectional study," BMC Nurs., vol. 17, no. 10, pp. 1-9, 2018.

[4] F. Letose, B. Admassu, and G. Tura, "Birth preparedness, complication readiness and associated factors among pregnant women in Agnuak zone, Southwest Ethiopia: a community based comparative cross-sectional study," BMC Pregnancy Childbirth, vol. 9, pp. 1-15, 2020.

[5] R. Sileshi, "Assessment of The Prevalence and Associated Factors of Birth Preparedness and Complication Readiness Among Pregnant W0men in Public Health Centers of Addis Ababa, Ethiopia," Addis Ababa University, 2019.

[6] K. E. RC Onoh, JO Egede, LO Lawani, and B. A., LO Aja, "Birth Preparedness and Complication Readiness Among Women of Reproductive Age Group in Abakaliki, Southeast Nigeria," Niger. J. Clinical Pr., vol. 23, no. 3, pp. 362-370, 2020.

[7] P. Smeele, R. Kalisa, M. Van Elteren, J. Van Roosmalen, and T. Van Den Akker, "Birth preparedness and complication readiness among pregnant women admitted in a rural hospital in Rwanda," $B M C$ Pregnancy Childbirth, vol. 18, no. 190, pp. 1-7, 2018.

[8] T. I. Tanha, D. Power, D. Company, and S. Khandker, "Birth Preparedness and Complication Readiness (BPCR) Among the Birth Preparedness and Complication Readiness (BPCR)," JOPSOM, vol. 37, no. 1, pp. 9-16, 2018.

[9] L. T. Utomo and F. Wahyudi, "Perancangan Aplikasi Ensiklopedia Kehamilan Hari Demi Hari Berbasis Android Guna Meminimalisir Kematian Pada Ibu Hamil," G-Tech (Jurnal Teknol. Ter., vol. 3, no. 1, pp. 12-15, 2019.

[10] K. E. N. Putra, "Aplikasi Posyandu Kesehatan Ibu Dan Anak Berbasis Android," Universitas Islam Indonesia, 2018.

[11] A. Asbihani, "Aplikasi Ibu Hamil Resiko Tinggi Berbasis Android Dengan Menggunakan Metode LBS (Location Based Service)," JATI (Jurnal Mhs. Tek. Inform., vol. 2, no. 1, pp. 115-122, 2018.

[12] V. Prasad, "Efficacy of an Electronic Application to Moderate Symptoms of Postpartum Depression and Improve Postpartum WellBeing: A Pilot Study," Texas A\&M University-Corpus Christi, 2018.

[13] M. O. H. Jasri and A. Buhari, "Rancang Bangun Kamus Kebidanan Berbasis Android Dengan Eclipse," vol. 02, no. 01, pp. 39-44, 2016.

[14] I. Sommerville, Software Engineering, Ninth Edition. United States: Pearson, 2015.

[15] A. Ghaaliq, L. Mb, C. Frca, A. Mccluskey, and M. B. Chb, "Clinical tests: sensitivity and specificity," Contin. Educ. Anaesthesia, Crit. Care Pain, vol. 8, no. 6, pp. 221-223, 2008.

[16] J. J. Dziak, D. L. Coffman, S. T. Lanza, R. Li, and L. S. Jermiin, "Sensitivity and specificity of information criteria," Brief. Bioinform., vol. 00, no. January, pp. 1-13, 2019.

[17] G. A. Azeze, T. M. Mokonnon, and M. W. Kercho, "Birth preparedness and complication readiness practice and influencing factors among women in Sodo town, Wolaita zone, Southern Ethiopia, 2018; community-based cross-sectional study," Reprod. Health, vol. 16 , no. 39, pp. 1-12, 2019.

[18] E. W. Faridah Hariyani, Ni Nyoman Murti, "Hubungan Usia, Paritas, Dan Kelas Ibu Hamil Dengan Komplikasi Persalinan Di Rskb Sayang Ibu Balikpapan," Mahakam Midwifery Journla, vol. 2, no. 5, pp. 361374, 2019.

[19] O. Maoz, T. Wainstock, E. Sheiner, and A. Walfisch, "Immediate perinatal outcomes of postterm deliveries," J. Matern. Neonatal Med., vol. 0, no. 0, pp. 1-6, 2018.

[20] R. Sigit, K. Danny, P. Nadiyah, and H. Yuniarti, "Automatic Detection of Fetal Head and Fetal Measurement on Birth Time Estimation," Int. J. Adv. Sci. Eng. Inf. Technol., vol. 10, no. 2, pp. 447-454, 2020.

[21] A. K. Susi Yunita Haryanti, Dina Rahayuning Pangestuti, "Anemia Dan Kek Pada Ibu Hamil Sebagai Faktor Risiko Kejadian Bayi Berat Lahir Rendah (BBLR)," J. Kesehat. Masy., vol. 7, no. 1, pp. 322-329, 2019.

[22] H. Wulandari, "Gambaran karakteristik bayi baru lahir yang mengalami asfiksia di rsu pku muhammadiyah kabupaten bantul yogyakarta," Universitas Aisyiyah Yogyakarta, 2019. 
[23] K. Aini, "Hubungan Kek Dengan Kejadian Stunting Pada Baduta Usia 6-24 Bulan Di Wilayah Kerja Puskesmas Pabelan Kecamatan Pabelan Kabupaten Semarang Tahun 2019," Semarang, 2019.

[24] S. R. Marthia Ikhlasiah, "Hubungan Antara Komplikasi Kehamilan Dan Riwayat Persalinan Dengan Tindakan Sectio Caesarea Di Rumah Sakit Fatimah Serang," J. JKFT, vol. 2, no. 2, pp. 1-7, 2019.

[25] A. Hasliani, "Hubungan Riwayat Hipertensi Dengan Kejadian Preeklampsia di RSUD Pangkep,” J. Ilmu Kesehat. Diagnosis, vol. 12, no. 1, pp. 93-98, 2018.

[26] S. F. Gary Cunningham, Leveno, Bloom, Spong, Dashe, Hoffman, Casey, Williams Obstetrics, 24th editions. Mc Graw Hill, 2014.

[27] K. Tunkyi and J. Moodley, "Anemia and pregnancy outcomes: a longitudinal study," J. Matern. Neonatal Med., vol. 0, no. 0, pp. 1-5, 2017

[28] T. A. P. Mohamed Abdelaziz Youssry, Ahmed Mohamed Radwan, Mohamed Amin Gebreel, "Prevalence of Maternal Anemia in Pregnancy: The Effect of Maternal Hemoglobin Level on Pregnancy and Neonatal Outcome," J. Obstet. Gynecol., vol. 8, pp. 676-687, 2018.

[29] M. Mohd Andalas, Cut Rika Maharani, Risa Anggia, Layyina Misqa, "Recurrent Preeclampsia with Twin Pregnancy: A Case Report in Zainoel Abidin General Hospital," Int. J. Clin. Med. Public Heal., vol. 1, no. 1, pp. 9-12, 2019.

[30] B. Feng, J. Zhai, and Y. Cai, "Effect of twin pregnancy chorionic properties on maternal and fetal outcomes," Taiwan. J. Obstet. Gynecol., vol. 57, no. 3, pp. 351-354, 2018.

[31] A. Bharti, P. Singh, and N. Nalini, "Observation of cases of antepartum hemorrhage in respect to fetal outcome, maternal morbidity and mortality in a tertiary referral center," vol. 06 , no. 08 , pp. $802-808$,
2018.

[32] M. Musyahida, "Hubungan Asfiksia Neonatorium dan Fraktur Clavikula Dengan Persalinan Pervaginam Letak Sungsang," J. Fenom. Kesehat., vol. 02, no. 01, pp. 208-214, 2019.

[33] A. G. N. Lenna Maydianasari, "Dukungan Tenaga Kesehatan Dalam Pemanfaatan Layanan Provider Initiated Testing and Counseling (Pitc) Selama Kehamilan," in Seminar Nasional UNRIYO, 2019, pp. 394 402.

[34] D. Sarli, "Analysis of Maternal and Perinatal Labour Complications with Mother Who Have Gestational Diabetes Mellitus," vol. 3, no. April, pp. 17-24, 2019.

[35] M. Bashir et al., "Type 2 diabetes mellitus in pregnancy: the impact of maternal weight and early glycaemic control on outcomes," Elsevier Ireland Ltd, 2018.

[36] H. B. Bernstein, C. Jeffrey, and K. K. Leslie, "Hepatitis C in Pregnancy in the Era of Direct-acting Antiviral Treatment: Potential Benefits of Universal Screening and Antepartum Therapy," Clin. Obstet. Gynecol., vol. 61, no. 1, pp. 146-156, 2018.

[37] P. Biancone et al., "HIV screening in pregnant women: A systematic review of cost-effectiveness studies," Wiley, vol. April 12 t, no. January, pp. 1-20, 2017.

[38] Y. Ejigu and B. Tadesse, "HIV testing during pregnancy for prevention of mother-to-child transmission of HIV in Ethiopia," PLoS One, vol. August 9, pp. 1-11, 2018.

[39] N. K. K. Kaewkiattikun, "Birth preparedness and complication readiness among pregnant women attending antenatal care at the Faculty of Medicine Vajira Hospital, Thailand," Int. J. Womens. Health, vol. 10, no. 1, pp. 797-804, 2018. 